\title{
Praktik Kewargaan dalam Arena Institusi Informal Era Demokratisasi
}

\section{Insan Kamil}

\begin{abstract}
Most studies on citizenship have only focus on the practice of citizenship in the context of formal state institutions. On the other hand, there are relatively few studies discussing citizenship practices in informal institutions. Therefore, this study examines the practice of citizenship in Islamic boarding schools/pesantren in the form of bonds as jamaah. This article intends to map the operation of pesantren as a binder of social ties between its citizens, as well as the pattern of relations between kiai and santri. This research shows that pesantren acts as lebenschraum habitus which installs the perceptions and expressions of its citizens. Pesantren is also a locus of power that has a significant influence on political and civic practices. As a locus of power, there is symbolic capital which is represented and reproduced continuously so that the symbolic capital produces economic, social, and cultural capital. The surplus of capital owned by the lora enables them to transform from the habitus of pesantren, to the habitus of political society and the state through the mechanism of electoral democracy. Even though the pesantren with all their supporting elements have a clientelistic relationship pattern, there is a public morality that can be transformed to strengthen the democratization agenda in the future.
\end{abstract}

\section{Keywords}

Demos; habitus; symbolic capital; doxa; pesantren

\section{Pendahuluan}

Studi ini berangkat dari kegelisahan minimnya kajian tentang demos (kewarganegaraan) di era demokrastisasi Indonesia. Padahal menelaah demos sangat penting, baik secara teoritik maupun dalam praktik politik. Bukan hanya karena demos adalah subjek utama demokrasi, tetapi demos merupakan tujuan akhir demokrasi itu sendiri. Teoritisi demokrasi ternyata alpa menempatkan posisi strategis demos dalam kajian-kajian demokrasi. Mereka terlalu mementingkan desain-desain kelembagaan dan struktur ekonomi politik elit sembari tidak secara spesifik mengkaji demos sebagai unit analisis tersendiri dalam belantara kajian demokrasi. Sehingga demos mengalami esklusi dalam wacana politik di Indonesia.

Insan Kamil adalah Ketua Dewan Pimpinan Daerah Partai NasDem Kabupaten Situbondo.

\section{Corresponding Author:}

Insan Kamil, Dewan Pimpinan Daerah Partai Nasdem Kabupaten Situbondo, Indonesia. Email: sibratih.kamil01@gmail.com 
Ketertarikan pada isu ini dipicu oleh penegasan Purwo Santoso bahwa seharusnya demos (warga negara/rakyat) harus inheren dalam demokrasi. Bahkan Santoso menegaskan kealpaan mengkaji demos menjadi persoalan epistemik yang harus diulas dan dikaji lebih serius (Santoso 2004, 63). Ketertarikan semakin kuat ketika Amalinda Savirani $(2015,31)$ menyatakan bahwa demos adalah gagasan vital dalam demokrasi. Gagasan tentang demos disejajarkan dengan gagasan tentang public dalam menentukan kualitas demokrasi. Demos adalah warga negara yang aktif (active citizen) dalam mempengaruhi diskursus publik untuk tujuan melakukan kontrol terhadap pengambilan keputusan oleh pemerintah tentang urusan-urusan publik. Dalam konteks ini, public dibayangkan sebagai aktualisasi demos yang berbekal pada hak-hak yang telah dijamin. Dalam kerangka inilah kewarganegaraan (citizenship) diharapkan hadir. Savirani menegaskan bahwa kewarganegaraan menghendaki partisipasi politik dalam negara (Savirani 2015, 19-20).

Selama ini, demokrasi dibayangkan sebagai karakteristik negara. Satuan hitung dari demokrasi adalah negara, dan hal itu disebut dengan istilah sistem politik atau sistem pemerintahan. Haruskah demokrasi dikembangkan dengan negara, lebih khusus lagi nation-state atau negara bangsa, sebagai satuan hitungnya. Studi ini membayangkan demokrasi atau demokratisasi dari arah yang sebaliknya, dari warga negara dan kewarganegaraannya. Demokrasi dipelajari dari unsur-unsur terkecil yang membentuknya, warga negara. Sudah jelas, dalam rangka memahami demokrasi, kewarganegaraan senantiasa dikaitkan dengan pengelolaan publik. Hanya saja, publik yang dimaksudkan tidak harus dalam bingkai nation-state. Demokrasi perlu ditelaah dalam cakupan mikro, namun tetap dalam kesadaran makro.

Pada saat yang sama, demokrasi perlu ditelaah dari apa yang senyatanya dipraktekkan. Karena pertimbangan-pertimbangan tersebut, cakupan atau unit analisis dipakai dalam memahami demokratisasi dari cara pandang ini adalah pesantren. Studi yang telah dilakukan para pakar mendudukkan pesantren sebagai suatu sub-kultur, dan demokratisasi perlu dilacak keberadaan dan cara kerjanya dalam sub-kultur tersebut. Berangkat dari penegasan bahwa kewargaan adalah bagian intrinsik demokrasi (Bellamy 2008; Stewart 1995), studi ini berusaha memahami bagaimana warga negara dan kewarganegaraannya hadir dalam konstruksi sosial mikro pesantren. Studi ini bermaksud menganalisis konsepsi kewarganegaraan (citizenship) di dalam konteks praktik politik dan demokrasi lokal, dalam kekuasaan lora (tokoh agama).

Kajian ini bukan sekedar mendiskusikan bagaimana pesantren hadir dan beroperasi dengan perilaku yang khas, melainkan juga sebagai penggalang kebersamaan. Dari sisi inilah kewargaan akan dirunut lebih lanjut. Pesantren telah menjadi entitas pengelola ke-publik-an warga. Ada unit pengelola publik yang menormalkan warga (yang kemudian disebut sebagai santri) untuk menambatkan nasibnya, menambatkan solusi bagi permasalahan-permasalahan yang dihadapinya. Perlu ditegaskan dari awal, simpul ini bukanlah birokrasi pemerintah, dan cakupan kewarganegaraan yang diuntainya jauh lebih sempit dari negara. Kalaulah "Kabupaten BM" (pengganti nama asli kabupaten) sebagai entitas 
administrasi negara dijadikan pembanding, maka pesantren menggalang kebersamaan warga yang jumlahnya lebih kecil. Hanya saja, kekhasan yang ditempanya dari waktu ke waktu, pengaruh setiap pesantren bersifat silangmenyilang, dan tidak jarang pengaruh itu jauh melampaui wilayah administrasi kabupaten tersebut.

\section{Literature Review}

\section{Konstruksi Kewarganegaraan untuk Demokrasi}

Studi ini dilakukan dengan keyakinan bahwa demokratisasi adalah persoalan pembudayaan nilai-nilai demokrasi, dan nilai-nilai itu sudah ditegakkan oleh masyarakat dalam habitus ataupun sub-kultur dimana mereka hidup. Demokratisasi itu adalah persoalan triger perubahan yang didasari pemetaan akan kaitan satu hal dengan hal lain; kaitan antara dinamika mikro dengan dinamika makro. Triger itu antara lain adalah pewacanaan kewarganegaraan dalam pemikiran demokrasi di Indonesia masih menempati posisi pinggiran. Dalam kata pengantar buku Vegitya R. Putri, berjudul "Watak Hibridasi dalam Wacana Citizenship di Indonesia", Purwo Santoso (Putri 2012) menilai kajian kewarganegaraan di Indonesia sudah sangat terlambat. Menurutnya di masa Orde Baru kajian citizenship bersifat dogmatis dan state-crafthood. Kajian citizenship dilakukan untuk melayani selera negara. Sementara pasca Orde Baru, gerakan prodemokrasi tidak mengontekstualisasi wacana citizenship ke dalam agenda-agenda demokratisasi. Hal inilah menurut Purwo Santoso menjadi awal petaka demokrasi.

Kewarganegaraan adalah sisi lain dari demokrasi. Ketidaksetaraan, kalau bukan keterbelakangan kewarganegaraan seorang santri dihadapan lora/kiai, bisa dibaca sebagai situasi yang tidak demokratis. Hal ini berlaku juga dalam komunitas yang lebih luas. Problem krusial demokrasi Indonesia sejak agenda reformasi dipancangkan adalah penyingkiran prinsip-prinsip kewarganegaraan. Herry Priyono (dalam AE Priyono dan Usman Hamid 2014) menelaah persoalan ini dengan membedakan dua jenis fundamentalisme yang menjadi sebab kewarganegaraan semakin terpinggir. Keduanya adalah fundamentalisme agama yang memproyeksikan kehidupan berbangsa/ bernegara atas dasar doktrin agama dan fundamentalisme pasar yang mendasarkan gagasan berbangsa/bernegara atas daulat transaksi pasar (Priyono 2014, 391).

Menjadi warga negara yang aktif dalam menggeluti persoalan publik (demos) dalam dua fundamentalisme ini hanya soal kebetulan. Akibatnya demokrasi menjadi korban karena landasan utamanya kewarganegaraan dilenyapkan. Padahal, tanpa prinsip dan nilai kewarganegaraan, kita akan mengalami kesulitan membangun demokrasi yang kuat. Senada dengan Priyono, Syafii Maarif berpandangan bahwa siapapun dan untuk alasan apapun yang melenyapkan kewarganegaraan berarti melakukan de-demokratisasi dan anti-demokrasi (Priyono 2014, 393; Maarif 2009, 9). Aktivasi demos merupakan elemen kunci dalam membangun tatanan demokrasi.

Demokrasi tidak berada dalam ruang hampa tanpa wujud. Ia berada dalam konstruksi sosial tertentu yang dipengaruhi dan mempengaruhi bagaimana 
demokrasi dipraktikkan. Sejak 1998 agenda demokratisasi tidak terjadi dalam ruang kosong religio-kultural dan ekonomi-politik (Priyono 2014, 391). Beragam kepentingan dan ide menubuh dalam demokrasi. Begitu pula demokrasi dan demokratisasi bersentuhan dengan ide-ide tertentu yang sudah lama berlaku di dalam masyarakat.

Rueschemeyer menjelaskan bahwa ide-ide sangat mempengaruhi bagaimana rakyat (people) mengembangkan preferensi dan memobilisasi mereka untuk terlibat dalam gerakan sosial dan politik. Ide memainkan peran penting di dalam mengajukan diagnosa kritis dan solusi yang efektif untuk mendorong aksi-aksi kolektif demi kepentingan bersama (Rueschemeyer 2006, 243-244). Menurutnya ide memiliki dimensi positif untuk mendorong perubahan sosial seperti "Pencerahan" yang mempengaruhi Revolusi Prancis dan dimensi negatif untuk mempertahankan status quo, seperti doktrin "hak-hak ilahi raja" Eropa setelah Abad Pertengahan (Rueschemeyer 2006, 227).

Di satu sisi, pesantren adalah bagian tak terpecahkan dari masyarakat yang lebih luas, namun pada saat yang sama ada kekhasan. Dalam praksis sosial pesantren menubuh ide-ide yang diterima sebagai doxa yang menginstalasi polapola relasi lora-santri dan membentuk konstruksi sosial di dalamnya. Yang dimaksudkan "ide" di sini adalah termasuk kepercayaan-kepercayaan (beliefs), nilai-nilai (values) dan norma-norma (norms) pesantren yang mengikat santri pada lora/kiai. Setiap ide bersifat otonom dari kepentingan audiensnya. Di dalam tubuh kultural pesantren yang penuh ide inilah ide kewarganegaraan bersinggungan.

Dalam habitus pesantren di Kabupaten BM terdapat ide-ide yang menentukan konstruksi sosial dan politik seperti tergambarkan dari bagaimana santri mengkonsepsikan diri mereka di hadapan lora-lora "Bani Fulan" (pengganti nama asli) dan bagaimana pula lora-lora mengkonstruksikan santri di hadapan kekuasaan mereka. Bagi seorang santri setidaknya ada lima ide yang menginstalasi perilaku mereka dan mengkonstruksi relasi mereka dengan lora, yaitu: pertama, kepatuhan diri pada guru; kedua, penghormatan pada guru; ketiga, kerendahan hati di hadapan guru; keempat, pengabdian total pada guru dan kelima, keberkahan hidup (barokah) dari guru. Meminjam Bourdieu (1977) ide-ide tersebut disebut doxa, sesuatu yang taken for granted, dianggap sebagai kebenaran dan oleh karena itu tidak perlu lagi dipertanyakan (universe of undisputed). Santri maupun lora menerima ini sebagai ortodoxa yang lalu melanggengkan kuasa lora atas santri. Tanpa disadari telah terjadi penguasaan atas yang lain dalam habitus pesantren.

Dalam konteks ini pesantren bukan lagi sebagai "locus of culture" akan tetapi lebih daripada itu pesantren adalah "locus of power". Kekuasaan bekerja secara sempurna dalam relasi lora dan santri di dalam pesantren. Dalam relasi kuasa ini menggejala politik ide yang bekerja sebagai instrumen kekuasaan lora atas santri. Relasi kuasa ini berlangsung melalui politisasi ide sebagai instrumen penguasaan. Mengikuti Jennifer L. Hochschild kelima ide yang terdapat dalam pesantren memperlihatkan tiga hal. Pertama, identitas santri sebagai "murid" dan bagaimana mereka berelasi dengan lora sebagai "guru". Kedua, moralitas seorang santri, berhubungan dengan bagaimana mereka menilai sesuatu baik-buruk, benar-salah 
ketika berhadapan dengan lora. Ketiga, interpretasi mereka tentang ke-santri-an dan ke-lora-an (Hochschild 2006, 285). Ketiganya membentuk konstruksi sosial kehidupan pesantren dan para warganya.

Urgensi untuk menelaah demokrasi dari skala mikro ini terasa urgen dalam merespon perubahan perpolitikan di negeri ini. Berakhirnya sentralisme politik Orde Baru dengan pendukung utamanya militer dan birokrasi menyediakan arena baru politik pada tingkat lokal (Priyono, Samadhi, and Tornquist 2007). Pergeseran lokus politik yang semula tersentral di pusat, kini terdistribusi ke lokal, memberikan dampak tersendiri bagi studi-studi tentang demokrasi Indonesia pasca Soeharto. Sebelumnya studi mengenai politik Indonesia lebih memusatkan diri pada Negara Orde Baru yang kuat dan terpusat mulai bergeser ke arah titik tolak pada peristiwa-peristiwa dan pemahaman-pemahaman lokal mengenai politik Indonesia (Nordholt 2005, 41, 45-46).

Keperluan untuk mendalami perilaku khas ini begitu terasa ketika di Indonesia berlangsung perubahan politik yang ditandai oleh desentralisasi. Penting untuk digarisbawahi dan dicermati bukan hanya lokusnya yang berpindah dari level nasional ke level lokal, melainkan unit analisis yang perlu diberlakukan untuk mencermati perubahan: dari unit makro, yang biasanya didekati secara ketatanegaraan ke unit mikro, yang biasanya didekati secara antropologis.

Sebetulnya, telaah sejenis ini telah dikaji oleh Abdur Rozaki (2004). Ilmuwan muda ini menelisik basis kultural dominasi kekuasaan politik lora yang disandarkan pada dua kultur keulamaan dan keblateran yang melekat pada sosok "Lora". Berdasar dua basis kultural tersebut "Lora" tampil sebagai sosok pemimpin yang disegani sekaligus ditakuti oleh masyarakat. Dalam studi lanjutannya Abdur Rozaki (2016) menunjukkan bahwa dengan modalitas kultur keagamaan dominan ada seorang "Lora" yang menjelma sebagai orang kuat lokal yang berkembang menjadi oligarki lokal dengan topangan karisma kakek-nenek moyangnya.

\section{Kerangka Konseptual: Habitus, Modal Simbolik, Arena, dan Doxa}

Dalam konteks studi ini, kewarganegaraan dipengaruhi oleh bagaimana subkultur pesantren distrukturkan dan menstrukturkan ulang persepsi dan perilaku para warganya. Habitus digunakan sebagai tools of analysis untuk mengenali corak, dan bekerjanya kewarganegaraan serta pola-pola relasi lora-santri. Sub-kultur pesantren distrukturkan dan mengstrukturkan ulang habitus sekaligus memberikan ekspresi yang bisa diinternalisasi sekaligus dieksternalisasi oleh lora dan santri. Melalui penstrukturan struktur yang dihasilkan oleh habitus, pesantren memproduksi ide-ide (ideas) sebagai pembentuk dan penopang relasi subordinatif antara lora dan santri. Di dalam habitus pesantren dan penegakan ide-ide tersebut warga pesantren (lora dan santri) berada dalam siklus: (1) matrix of perception (matriks persepsi); (2) appreciations (apresiasi); dan (3) actions (tindakan) (Bourdieu 1977, 83). Intinya, ketiganya merupakan cerminan dari habitus seseorang. Tindakan yang merupakan cerminan habitus tersebut, kemudian, secara perlahan-lahan menjadi realitas objektif, dan diinternalisasi ulang hingga mempunyai hubungan dialektis dan menghasilkan tindakan-tindakan baru untuk meresponnya (Bourdieu 1977, 83). 
Dalam kerangka Bourdieu, habitus merupakan struktur mental dan kognitif di mana skema atau pola diinternalisasi oleh aktor untuk memahami, merasakan, bertindak dan menilai dunia sosial. Tindakan aktor atau individu menurut Bourdieu bukanlah semata-semata produk dari struktur yang melingkupinya, namun tindakan yang dipilih juga didasarkan atas rasionalitas pelaku. Bourdieu menjelaskan konsep habitus-nya sebagai berikut:

"Sistem disposisi yang bertahan lama, dapat berubah-ubah, struktur-struktur yang terstruktur berkecenderungan untuk berfungsi sebagai strukturstruktur yang mengalami proses penstrukturan, sehingga, sebagai prinsipprinsip penerusan dan penstrukturan praktik-praktik dan representasirepresentasi yang dapat secara objektif 'diatur' sekaligus 'teratur' tanpa, dengan cara apapun, menjadi hasil [bentukan] sikap ketundukan terhadap berbagai aturan, yang secara objektif disesuaikan dengan tujuan-tujuan mereka tanpa perlu mensyaratkan suatu upaya untuk mencapai tujuan secara sadar atau suatu ungkapan penguasaan atas tindakan-tindakan yang perlu ditempuh untuk meraihnya dan, dengan ini semua, secara kolektif diorkestrasikan tanpa perlu menjadi hasil dari tindakan pengorkestrasian oleh seorang konduktor (Bourdieu 1977, 72)."

Habitus merupakan sesuatu yang mengendap lama, menempati posisi yang amat dalam pada diri seseorang, hingga menjadi watak yang telah terstruktur akut. Lalu, sesuatu ini dapat pula menstruktur ulang dan menempati posisi penting sehingga memberikan pengaruh pada proses menstrukturnya struktur. Habitus juga merupakan prinsip-prinsip yang bersifat generatif, bertolak dari kesejarahan yang posisinya melekat dalam diri seseorang, ditentukan oleh hal-hal lain di luar manusia yang mampu membentuk diri seseorang atau menjadi aturan itu sendiri (Thohari dan Harjo 2021, 64).

Merujuk Ricard Jenkins, habitus berakar serta beroperasi dalam tubuh manusia. Habitus berada di dalam kepala aktor dan mempengaruhi praksis dan interaksi aktor di lingkungan yang melingkupinya, meliputi cara bicara, bergerak, dan yang lainnya (Jenkins 2004, 107-108). Habitus merupakan "a dialectic of internalization of externality and the externalization of internality" (dialektika internalisasi eksternalitas dan eksternalisasi internalitas (Bourdieu 1977, 72). Dengan demikian, habitus juga mempunyai kemampuan untuk memproduksi praksis sekaligus produk dari praksis. Habitus merupakan suatu proses dan kesatuan yang tidak pernah selesai, suatu sejarah yang terus saja berlanjut (Jenkins 1992, 79-80) yang memproduksi tindakan individu secara kolektif (Bourdieu 1990, 54).

Dalam setiap habitus selalu terdapat capital. Bahkan keduanya tidak bisa dipisahkan. Definisi capital Bourdieu berbeda dan khas dibandingkan dengan pelbagai definisi capital yang sudah banyak diulas ilmuwan sosial lainnya. Bourdieu mengajukan alternatif berbagai bentuk capital yaitu; ekonomi, sosial, budaya dan simbolik. Untuk kepentingan unit analisis kajian ini penulis menggunakan modal simbolik (symbolic capital). Dalam kerangka Bourdieu modal 
simbolik merupakan paripurna dari transformasi tiga modal yang lain. Untuk mencapai modal simbolik, seseorang atau kelompok harus memiliki tiga modal yang lain terlebih dulu. Mereka akan mendapat pengakuan dari yang lain jika sudah mengakumulasi modal simbolik.

Kekuasaan simbolik memberikan legitimasi pada keberadaan dominasi dan reproduksi relasi kekuasaan (Stokke dan Selboe 2009, 63). Konsep modal simbolik mengurai pengaruh simbol-simbol yang terus-menerus direproduksi dan direpresentasi oleh santri maupun lora dalam perkataan, pengakuan, dan atau tindakan sehari-hari sehingga terbentuk mistifikasi simbol, yang dalam hal ini melekat pada sosok Kiai Fulan. Pada akhirnya modal simbolik menyediakan pengakuan dan totalitas (Stokke dan Selboe 2009, 65) pengabdian santri kepada lora.

Di dalam konsepsi Bourdieu, field bertautan dengan habitus, capital, dan ini menghasilkan suatu formula yang penting: [(habitus) $($ capital)] + field = practice (Bourdieu 1984, 101). Ulasan Bourdieu mengenai habitus, field, dan capital tersebut dapat dijelaskan bahwa segala uborampe modal selalu menubuh dalam habitus. Atau, lebih tepatnya, pada habitus selalu menempel modal di dalamnya, yang secara terus-menerus ikut dalam proses bergulatnya habitus. Dengan modal, habitus dapat melakukan kreasi-kreasi, yang pada saat bersamaan berhadapan dengan field atau struktur. Field menyediakan seperangkat aturan yang harus diikuti dan dilakukan. Di dalam field pesantren sekaligus beragam ide tersedia, dan karena tidak ada heterodoxa [ide-ide baru] yang sanggup menantangnya maka ia [ide-ide dalam sub-kultur pesantren] menjadi doxa.

Pesantren berikut ide-ide di dalamnya melahirkan doxa yang tidak mengalami interupsi dari luar. Ide-ide inilah menjadi doxa politik yang dijaga sedemikian rupa baik oleh lora maupun santri. Dalam setiap arena sosial selalu terdapat doxa yang menggambarkan kesesuaian yang diterima sebagai sesuatu yang taken for granted, dianggap sebagai kebenaran dan oleh karena itu tidak perlu lagi dipertanyakan (universe of undisputed). Dalam konteks pesantren, doxa ini dijaga oleh kedua belah pihak, lora dan santri. Keduanya ikut melanggengkan doxa dalam relasi yang klientelistik.

Mengikuti Bourdieu biasanya kelompok dominan selalu ingin mempertahankan doxa karena menguntungkan bagi status quo. Mereka berusaha mempertahankannya dengan segala cara, sementara bagi mereka yang terpinggirkan berusaha untuk menghancurkan doxa dan menggantinya dengan yang lain. Pertentangan terhadap doxa yang dilancarkan oleh kelompok yang dirugikan disebut heterodoxa, mereka akan membangun nilai-nilai dan kepercayaan-kepercayaan yang berkebalikan dengan doxa yang dibangun oleh kelompok dominan yang disebut ortodoxa (Bourdieu 1977).

\section{Metode}

Studi ini merupakan penelitian kualitatif untuk mempelajari bagaimana kewarganegaraan hadir di dalam konstruksi sosial pesantren dan relasi santri-lora dalam praktik politik lokal. Inti penelitian ini melacak secara mendalam 
keberadaan demos (kewarganegaraan) di dalam praktik politik yang menempatkan kalangan lora sebagai penguasa. Untuk keperluan tersebut penelitian ini diarahkan untuk memperoleh kedalaman (richness) jawaban dari setiap informasi yang disampaikan oleh para informan kunci. Kajian ini menggunakan metode etnografis untuk mengambarkan secara detail bagaimana santri mengkonstruksi diri mereka dan lora. Juga sebaliknya bagaimana lora memposisikan dirinya di hadapan santri. Penulis mencatat semua informasi, ucapan dan perilaku secara teliti dan rinci (Hammersley dan Atkinson 2009) dari berbagai informan yang terdiri dari kalangan lora, santri, dan klebun yang bisa memberikan penjelasan tentang seluk-beluk politik kuasa lora kaitannya dengan keberadaan demos.

Untuk keperluan ini, penulis melakukan dua kali kunjungan. Pada kunjungan pertama penulis tinggal di "Pondok Pesantren" selama kurang lebih dua bulan terhitung mulai 1 Oktober hingga akhir November 2012. Kunjungan kedua dilakukan pada tanggal 1 hingga 15 April 2015. Selama masa itu penulis mengumpulkan data dengan menggunakan metode observasi partisipan (participant observation) dan sekaligus juga wawancara mendalam. Wawancara mendalam dan intensif dilakukan dengan para informan yang terdiri atas kalangan lora yang terlibat dalam politik lokal, misalnya lora yang menjadi anggota DPRD, wakil bupati, pengurus partai dan tim sukses Pilkada. Selain wawancara formal penulis juga terlibat dalam pembicaraan informal dengan mereka untuk memperdalam data-data yang dibutuhkan. Melalui perbincangan informal, penulis memperoleh informasi-informasi yang tidak didapatkan pada wawancara formal. Sedikitnya terdapat tujuh orang lora yang terlibat dalam wawancara dan perbincangan informal dengan penulis. Mereka mewakili keluarga lora yang belakangan diketahui terpolarisasi ke dalam empat kelompok berdasarkan kepentingan politik. Selain lora, informan lain yang diwawancarai terdiri dari para santri. Santri dan lora menjadi informan utama dalam studi ini.

Selain wawancara mendalam dengan lora dan santri, penulis melakukan observasi partisipan (participant observation), sebuah metode di mana penulis melibatkan diri dan menjadi bagian dari realitas yang diteliti (Atkinson dan Hammersley 2009, 316-317). Penulis berpartisipasi, misalnya, dalam kegiatankegiatan pengajian yang diselenggarakan di pondok pesantren maupun di desadesa, ziarah makam, diba'an, sholawatan, tahlilan, pertemuan-pertemuan dan kegiatan-kegiatan yang lain sehari-hari informan. Selama melakukan observasi partisipan penulis memutuskan tinggal di "Pesantren". Temuan-temuan dalam kegiatan observasi partisipan dicatat dan dihubungkan dengan catatan wawancara sehingga keduanya berlangsung secara simultan dalam proses tunggal yang kompleks (Spradley 2006, 97).

\section{Hasil dan Pembahasan}

\section{Subkultur Pesantren: "Sekat” Perubahan Menuju Demokrasi?}

Problematika kewarganegaraan, khususnya dalam rangka menegakkan demokratisasi muncul, manakala kita sadari bahwa perilaku yang terpola di 
pesantren telah berkedudukan sebagai institusi kultural yang begitu khas dan mapan, atau sub-kultur yang berbeda dengan kultur masyarakat pada umumnya. Menggejalanya pesantren sebagai sub-kultur ini diakui, bahkan dipopulerkan oleh tokoh sentral pesantren, Abdurahman Wahid (1974). Menurut Wahid sebagai subkultur pesantren memiliki tiga ciri minimum yang membedakannya dengan masyarakat di luar pesantren sebagai berikut: pertama, cara hidup yang dianut; kedua, pandangan hidup dan tata nilai yang diikuti; dan ketiga, hierarki kekuasaan intern yang dipatuhi.

Semenjak saat itu, sebagaimana terlihat dalam karya Hadimulyo (1985), pesantren tampil sebagai "institusi kultural" yang memiliki karakteristik tersendiri. Kehidupan pesantren didasarkan pada nilai, kepercayaan, norma, aturan dan tradisi yang membentuk pola-pola dan disposisi-disposisi pada anggotanya. Hubungan kiai-santri telah terpola sebagai habitus. Dalam konteks ini, pesantren berperan sebagai arena kultural dan politis yang melibatkan santri dan kiai; bahkan antara santri dengan putra kiai (lora).

Dibalik penggunaan istilah 'pesanten sebagai sub-kultur' memang ada derajat isolasi. Namun, isolasi itu lebih dikarenakan kokohnya konstruksi sosial yang diadopsi dan ditegakkan secara bersama-sama dan terus-menerus daripada karena isolasi fisik belaka. Ada kebajikan dalam skala mikro (dunia pesantren) yang tidak berlaku dalam skala makro (masyarakat umum). Hanya saja, ini bukan penyimpangan. Kekhususan itu tetap menjadi rujukan yang perlu direproduksi, bukan penyimpangan yang harus dihindari. Kiai, yang menjadi poros dari subkultur ini, bahkan terekspose ke "dunia luar", mereka disebut sebagai makelar budaya (cultural broker) (Geertz 1960; Horikoshi 1974).

Melalui karya "The Javanes Kijaji: the Changing Roles of a Cultural Broker", Geertz menjelaskan fungsi medioker kiai sebagai makelar budaya (cultural broker) yang menghubungkan pesantren dengan dunia luar menjadi penentu keberhasilan pesantren beradaptasi dengan perkembangan. Menurut Geertz kiai pesantren di pedesaan Jawa Timur telah secara aktif membawa nilai-nilai modernisasi ke dalam pesantren sambil merawat tradisi pesantren yang sudah mengakar kuat. Seorang kiai di pesantren telah berdiri di antara modernitas dan tradisi. Hal-hal baik yang dibawa oleh modernitas dari kota sejauh tidak melemahkan tradisi maka akan diterima dan digunakan oleh pesantren (Geertz 1960).

Berbeda dengan Geertz, Horikoshi memperlihatkan kesimpulan teoritik bagaimana seorang kiai pesantren di pedesaan Jawa Barat. Menurutnya karena posisinya yang kuat, kiai menempati posisi penghubung antara masyarakat pedesaan-bangsa yang sedang berubah. Meski demikian para kiai ini bukan lagi satu-satunya kelompok yang memiliki akses ke dunia luar. Dalam peranan mediating, para kiai ini tidak hanya menahan arus dari luar, akan tetapi secara aktif mendorong perubahan mendasar terjadi di tengah-tengah masyarakat.

Hal menarik dari Horikoshi yang membedakannya dengan Geertz adalah kesimpulan teoritiknya bahwa peranan mediating kiai dalam perubahan sosial harus dilihat dari tiga hal: pertama, posisi sulit mereka dalam integrasi masyarakat-bangsa, hal ini memunculkan dilema bagi mereka, yang pada akhirnya dalam kasus kiai di pesantren Jawa Barat menyebabkan mereka memberikan 
loyalitas pada salah satunya karena dengan demikian mereka memiliki posisi kultural yang kokoh; kedua, posisi struktural mereka sebagai mediator di antara pengikut loyal mereka di pedesaan dengan jaringan masyarakat-bangsa yang sedang berubah dan ketiga, keuntungan yang mereka peroleh dari peranan sebagai mediator (Horikoshi 1987, 4-9).

Kekhususan ditandai bekerjanya ide-ide (ideas) yang terdapat dalam pesantren yang mempolakan relasi kiai-santri dan mengkonstitusi konstruksi sosial yang tidak hanya di dalam sub-kultur pesantren akan tetapi juga mempengaruhi masyarakat yang lebih luas. Ide-ide inilah yang kemudian menjadi doxa dan menyeruak ke arena di luar batas-batas sub-kultur pesantren. Pada titik ini ide kewarganegaraan maupun demokrasi berjumpa dengan ide-ide yang terdapat di dalam pesantren. Di sini titik paradoksalnya. Demokrasi yang dibayangkan sebagai kesetaraan dan partisipasi politik warga negara dalam bingkai negara-bangsa tersekat dan tersendat di hadapan ide-ide yang ada dalam sub-kultur pesantren dengan aktor utamannya kiai/lora. Ide-ide ini mengikat kuat warga pesantren sehingga mereka tidak mudah tertembus oleh ide-ide baru seperti demokrasi.

Bekerjanya ide-ide pada akhirnya menciptakan pola-pola klientelisme yang sangat kuat di antara warga pesantren: kiai dan santri. Hal ini memperlihatkan relasi kuasa di antara keduanya. Transformasi kiai dari habitus tradisionalnya, pesantren, ke arena baru komunitas politik (political community) dan negara (state) tidak lantas mengubah relasi klientelistik di antara mereka. Rasa ketaatan dan penghormatan santri kepada kiai mengalahkan asumsi-asumsi dasar relasi negarawarga negara. Realitas ini tergambarkan pada bagaimana masyarakat memberikan respons-melalui pernyataan dan tindakan-terhadap perilaku politik kiai di Kabupaten BM.

\section{Pesantren sebagai Lebenschraum Habitus}

Kabupaten BM didudukkan sebagai poros tatanan kehidupan pesantren, karena historisitas dan sentralitas peranan kiai selama ini. Hal ini ditandai oleh fungsi-fungsi yang dijalankan pesantren sebagai lembaga pendidikan Islam. Sangat langka ditemukan anak-anak orang Kabupaten BM yang tidak pernah nyantri di pesantren. Jarang sekali anak-anak mereka tidak ngelmu pada kiai, atau paling tidak sowan ke kiai di pesantren untuk kepentingan yang bermacam-macam, seperti minta dido'akan agar pekerjaan dan rezekinya lancar, dimudahkan urusannya, dijauhkan dari bahaya, mendapatkan jodoh, meminta kesembuhan dari penyakit, meminta barokah, dan lain-lain.

Di dalam kultur pesantren, kiai menjadi figur utama yang menjadi rujukan moral, etika, dan tingkah laku anggota komunitas pesantren. Bagi seorang santri, kiai adalah penunjuk dan penuntun jalan kebenaran menuju hidup yang diridhai oleh Allah. Bagi para santri, kiai tidak hanya sebagai guru di mana mereka belajar ilmu-ilmu agama tapi juga sebagai pembimbing spiritual yang memberikan nasehat-nasehat rohaniyah bagi kehidupan mereka. Tidak hanya sebagai guru agama dan pembimbing spritual, kiai-kiai di Pulau Jawa sebagaimana dideskripsikan oleh Bruinessen juga memiliki keahlian di bidang kanuragan dan 
kedigdayaan. Mereka memberikan latihan-latihan fisik dan ritual-ritual mistik untuk menambah ketangguhan bertarung dan kekebalan terhadap senjata tajam dan senjata api (Bruinessen 1994, 17-18).

Demikian pula kiai-kiai di Madura juga melakukan hal serupa. Bahkan mereka mendoakan, memberikan bacaan-bacaan hizib, dan membuatkan jimat-jimat tertentu bagi mereka yang akan melakukan carok, terutama untuk kehormatan istri. Seorang calon pelaku carok merasa harus terlebih dahulu nyabis kepada seorang kiai untuk tujuan apagar dengan meminta ijazah (Wiyata 2002, 48). Apagar dan ijazah merupakan upaya spiritual dan fisik yang dimaksudkan untuk melindungi diri sendiri dari mara bahaya yang datang dari luar/musuh. Karena perannya yang sangat penting itu, kiai menjadi sosok yang sangat dihormati dan diagungkan tidak hanya oleh santri, tetapi juga oleh orang tua santri bahkan oleh masyarakat secara umum. Kiai dan keluarganya telah menjadi lapisan sosial tersendiri yang memiliki berbagai privilege yang tidak dimiliki oleh masyarakat umum atau keluarga bukan keturunan kiai. Kiai dan keturunannya sungguhsungguh telah mewujud sebagai kasta tersendiri di dalam kultur masyarakat pesantren (Bruinessen 1994, 138).

Kabupaten BM dikenal sebagai daerah yang kental dengan tradisi pesantren. Berdasarkan kepada subkultur pesantren, Wiyata (2002, 47-48) mengelompokan masyarakat Madura ke dalam tiga lapisan sosial yaitu, keae (kiai), bindhere dan santre. Dalam pengelompokan ini kiai berada dalam lapisan sosial teratas, santri pada lapisan terbawah sementara bindhere berada pada lapisan menengah. Pengelompokan ini didasarkan pada keulamaan kiai sebagai pewaris para nabi dan pemimpin pesantren. Sementara bindhere adalah mereka yang sudah menyelesaikan pelajarannya di pesantren dan menguasai ilmu-ilmu agama di bawah tingkatan kiai. Sama seperti kiai, selain bidang agama, bindhere juga menjadi rujukan masyarakat pada bidang-bidang yang lain. Para bindhere ini berasal dari luar keturunan kiai.

Di Kabupaten BM, pesantren adalah ruang hidup (lebenschraum-habitus) yang mengatur tata hidup, nilai-nilai dan aturan-aturan yang harus dipatuhi oleh setiap anggotanya. Bagi mereka yang hidup dalam lingkungan kultur pesantren harus melaksanakan dan menundukkan diri di atas norma-norma yang berlaku jika tidak menghendaki tertolak dan terpental. Mengutip Kuntowijoyo, Rozaki menjelaskan bahwa pesantren dan kiai telah menjadi simbol keagamaan yang menginstalasi prinsip-prinsip etik (organizing principles) yang mampu membangun sentimen kolektif (collective sentiments) di antara mereka (Rozaki 2016,10).

Melalui pesantren dan kiai, orang Kabupaten BM menginternalisasi sekaligus mengeksternalisasi (Bourdieu 1977, 22) prinsip-prinsip dan nilai-nilai keagamaan. Sebagai sub-kultural, tata nilai pesantren terdiri dari unsur pembentuk, yaitu peniruan dan pengekangan. Unsur pertama dilakukan dengan meniru bagaimana para nabi dan para ulama salaf menjalankan hidup. Unsur kedua dilakukan dengan kepatuhan total para santri terhadap aturan-aturan pesantren (Wahid 1974, 45). Pengamatan terhadap keseharian masyarakat di Kabupaten BM memperlihatkan betapa pesantren telah menghabituasi santri khususnya, dan warga pada umumnya, dalam membangun persepsi mereka, memberikan apresiasi dan 
mendasarkan tindakan-tindakan mereka atasnya (Bourdieu 1977, 83). Melalui pesantren, mengikuti Blumer, santri dan warga mempertimbangkan, menguraikan, dan menilai hal-hal tertentu dan melalui kesadarannya merumuskan dan merencanakan perbuatan-perbuatannya (Veeger 1985, 224-226). Gambar berikut memperlihatkan bagaimana pesantren sebagai lebenschraum habitus membentuk pandangan, apresiasi, dan perilaku orang Kabupaten BM.

\section{Gambar 1. Matrik Pesantren sebagai Habitus Orang "Kabupaten BM"}

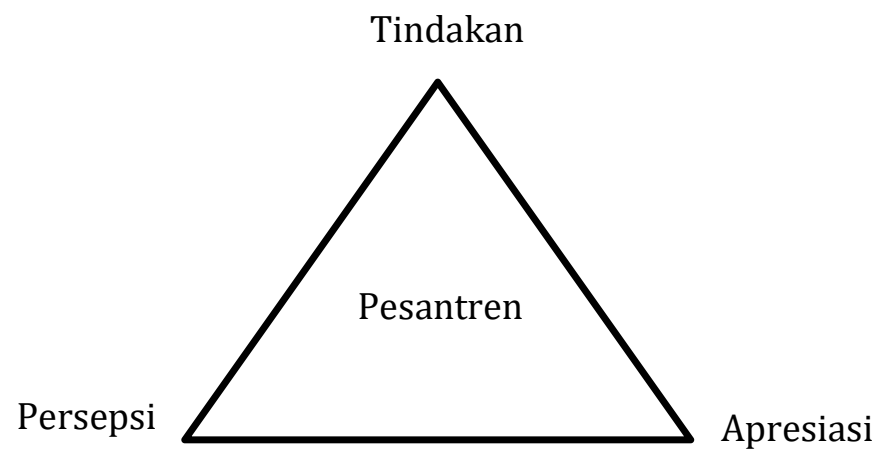

Di Kabupaten BM ini terdapat dua kelompok besar pesantren, yaitu pesantrenpesantren "bani Fulan" (nama aslinya sengaja tidak disebutkan) dan pesantrenpesantren di luar mereka. Rozaki $(2016,81)$ mengelompokkan kiai-kiai di daerah ini berdasarkan keturunan. Menurutnya top elite kiai adalah mereka yang berasal dari Bani Fulan, sementara yang bukan keturunan Bani Fulan disebut middle elite kiai. Studi ini memperlihatkan bahwa di dalam internal kiai pesantren Bani Fulan sendiri terdapat "pelapisan sosial" terutama jika dilihat dari pengaruh politik dan sosial mereka bagi masyarakat. Jaringan sosial dan posisi politik keturunan Kiai Fulan jalur "Pak Kiai" (pengganti nama asli) lebih kuat dibandingkan dengan keturunan Kiai Fulan jalur "Bu Nyai" (pengganti nama asli), seperti terlihat dalam gambar berikut.

\section{Gambar 2. Pelapisan Lora Berbasis Jaringan Sosial dan Posisi Politik}

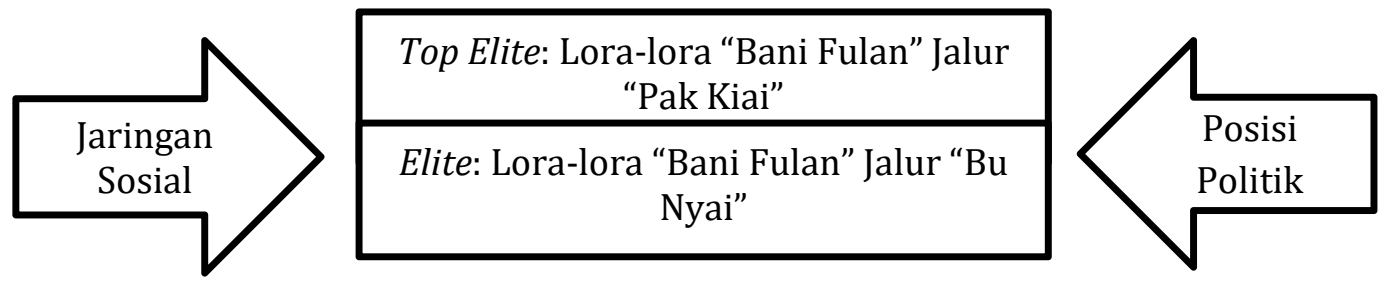

Kiai-kiai pesantren Bani Fulan jalur Pak Kiai memiliki tingkat pengaruh yang besar dan luas pada masyarakat Kabupaten BM dan jumlah santri yang sangat besar. Mereka juga memiliki pengaruh yang sangat kuat dalam bidang politik. Selain itu, mereka menduduki posisi-posisi penting baik dalam partai politik 
(political society) dan negara (state). Sementara jaringan sosial keturunan Bu Nyai tidak terlalu kuat, dan posisi politik mereka juga lemah dibandingkan dengan keturunan Pak Kiai. Studi ini menemukan bahwa tidak ada seorang pun keturunan Kiai Fulan dari Bu Nyai yang menduduki posisi formal baik itu di pemerintah/eksekutif maupun legislatif.

\section{Arena Praktik Kewargaan: Pesantren sebagai Lokus Kekuasaan dan Politis}

Pesantren tidak dapat dilihat hanya sebagai lokus kultural (locus of culture), akan tetapi sebagaimana temuan studi ini pesantren memperlihatkan bekerjanya kekuasaan. Dalam relasi lora-santri tergambar dengan jelas bahwa pesantren adalah lokus kekuasaan (locus of power) yang menempatkan kiai sebagai porosnya. Pesantren sebagai sub-kultur yang mengisolasikan diri dari masyarakat sekitarnya (Wahid 1974) dan kiai yang mengambil peranan sebagai cultural broker (Geertz 1960; Horikoshi 1987), di Kabupaten BM memperlihatkan bahwa pesantren selain sebagai locus kekuasaan juga sekaligus locus politis. Sebagai lokus kekuasaan (locus of power) pesantren memiliki pengaruh signifikan terhadap praktik politik (political field) dan corak kewargaan. Di sini dirasa perlu terlebih dulu untuk melacak kebiasaan-kebiasaan, nilai-nilai dan norma-norma kultural yang diyakini benar, dipraktekkan, dan dipertahankan oleh santri dan lora.

Hal di atas dilacak pada historisitas pembentukan pesantren sebagai tempat pembelajaran Islam yang telah membudaya dalam masyarakat Madura. Historisitas pesantren Bani Fulan tersentral pada sosok Kiai Fulan. Kiai Fulan tampil sebagai "simbol budaya dan agama" yang dipercaya memiliki karomah dan dapat memberikan barokah. Dalam konteks ini historisitas menyediakan instrumen legitimasi yang bekerja dalam habitus pesantren. Karena yang diceritakan mengandung keagungan simbol kolektif pesantren dari mana lora-lora Bani Fulan berasal. Historisitas juga berfungsi sebagai pengukuh supremasi kultural dan legitimasi politik lora-lora Bani Fulan atas santri, khususnya dan masyarakat Kabupaten BM, umumnya.

Daya tarik historisitas pesantren Bani Fulan berporos pada sosok Kiai Fulan yang memikat salah seorang keluarga bangsawan yang kagum dan terkesan dengan kealiman Kiai Fulan. Kemudian menikahkan putrinya, dengan Kiai Fulan. Pernikahan ini kelak membuat legitimasi kultural dan politik Kiai Fulan dan keturunannya di kalangan orang-orang Kabupaten BM semakin kuat dan kokoh. Di dalam diri keturunannya mengalir darah keulamaan dan kebangsawanan; dua hal yang dihormati oleh orang-orang Madura. Gelar kebangsawanan juga digunakan oleh lora-lora Bani Fulan. Mereka menggunakan dua gelar kultural sekaligus di depan nama mereka masing-masing, yakni RKH (R=Raden, K=Kiai, H=Haji). Gelar keulamaan, kebangsawanan dan keislaman memiliki makna simbolik yang ikut melegitimasi peranan sosial dan politik mereka di tengah masyarakat.

Lora-lora Bani Fulan memiliki modalitas simbolik berupa kultur keagamaan yang ditransformasikan dari ketokohan Kiai Fulan. Oleh para santri dan lora-lora keturunannya, Kiai Fulan dilukiskan sebagai tokoh mistik dan waliullah yang katakata dan tindak-tanduknya sebagai isyarat kebenaran atau sesuatu yang akan terjadi. Kadang semua apa yang dikatakan dan dilakukannya di luar pemahaman 
dan nalar "orang awam". Termasuk juga dalam mendidik santri-santrinya, banyak kejadian-kejadian nyeleneh yang dilakukan oleh Kiai Fulan kepada para santrinya yang kadang terkesan tidak masuk akal dan sulit dimengerti. Kiai Fulan seperti sudah mengetahui apa yang akan terjadi pada diri masing-masing santrinya kelak.

Pesantren bani Fulan memiliki model dan pola tersendiri dalam mendidik para santrinya. Model tersebut diberlakukan sejak Kiai Fulan dan diteruskan oleh keturunannya, yaitu: pertama pendidikan di pesantren bani Fulan lebih menekankan pada kekuatan batin dan ketaatan pada guru, antara lain sikap qana'ah, tawadhu' dan akhlaqul karimah; kedua, karena penekanan pada dimensi spiritual maka orientasi pada kemampuan keilmuan tidak mendapat porsi yang besar. Model pendidikan di pesantren bani Fulan berorientasi pada "barokah" daripada "keilmuan". Pesantren-pesantren Bani Fulan jika dibandingkan dengan pesantren di Jawa memiliki perbedaan mencolok (Wawancara, 20 Oktober 2012).

Barokah yang menjadi orientasi santri pesantren Bani Fulan selalu dikaitkan dengan sosok Kiai Fulan sebagai pancer lora-lora Bani Fulan. Rozaki menunjukkan bahwa ketokohan dan karisma Kiai Fulan direproduksi dan direpresentasi secara terus-menerus oleh para santri dan pengikutnya sehingga terjadi transformasi karisma pada trah keturunan Kiai Fulan (Rozaki 2016, 204). Lebih lanjut menurutnya transformasi karisma ini berpengaruh terhadap bidang-bidang lain di luar pesantren, termasuk dalam bidang politik kekuasaan. Rozaki menyimpulkan bahwa terdapat relasi yang kuat antara pengaruh keagamaan dan politik kekuasaan (religio-political power) di Kabupaten BM (Rozaki 2016, 106). Kaitmengkait antara pengaruh keagamaan dan kekuasaan ini yang semakin mengokohkan bahwa pesantren merupakan lokus kekuasaan yang mendapat legitimasi dari nilai-nilai keagamaan.

Transformasi budaya keagamaan pesantren dan politik kekuasaan dapat dilihat pada dua sosok keturunan Kiai Fulan. Dengan kapasitas masing-masing, dua orang keturunan trah Bani Fulan yang menonjol dalam melakukan transformasi karisma Kiai Fulan untuk alasan dan tujuan yang berbeda, dan dalam konteks yang berbeda pula. Ada yang menggunakan karisma yang dia miliki untuk tujuan "profetik" demi membela rakyat Madura menghadapi kekuasaan Orde Baru yang represif. Ada juga yang menggunakan karismanya demi tujuan "hegemonik" dan "dominatif" untuk merebut dan mempertahankan kekuasaan dalam era demokratisasi dan politik lokal di Kabupaten BM. Pada titik ini tergambar bahwa politik keagamaan tampil dengan dua wajah. Pertama, sebagai landasan etikasketik yang berpihak dan membela kepentingan-kepentingan rakyat kecil berhadapan dengan kekuasaan. Kedua, nilai keagamaan dijadikan alat politik kekuasaan yang hegemonik-koruptif dan menindas rakyat (Rozaki 2016).

Berkaitan dengan hal tersebut di atas, bahwa di dan melalui pesantren sebagai lokus kekuasaan terdapat modal simbolik (symbolic power) yang direpresentasi dan direproduksi terus-menerus sehingga dengannya lora-lora Bani Fulan mentransformasinya menjadi modalitas yang lain. Berbekal modal simbolik tersebut, ada Lora yang membangun jaringan sosial dan mendapat pengakuan sosial dari masyarakat Kabupaten BM, bahkan berhasil menjadi bupati untuk dua 
kali periode. Posisi politik ini semakin memperkuat jaringannya dengan orangorang penting di negeri ini.

Seakan membalik kerangka Bourdieu-an yang menyatakan bahwa modal simbolik adalah akumulasi dari tiga modal yang lain (ekonomi, sosial dan budaya) lora tersebut menunjukkan hal yang berbeda, yaitu modal simbolik mampu mendorong munculnya modal sosial hingga modal ekonomi. Demikian pula di pesantren modal simbolis ini berhimpitan dan tidak terpisahkan dengan modal kultural. Artinya, di pesantren Bani Fulan menubuh modal simbolik yang menghadirkan modal-modal yang lain (ekonomi, sosial dan budaya) yang, selanjutnya dengan akumulasi empat modal tersebut lora-lora Bani Fulan bergerak ke arah politik kekuasaan. Modal simbolis tersebut yang menjadi basis kekuasaan politik lora.

Gambar 3. Transformasi Modal Simbolik ke Arah Politik Kekuasaan Lora

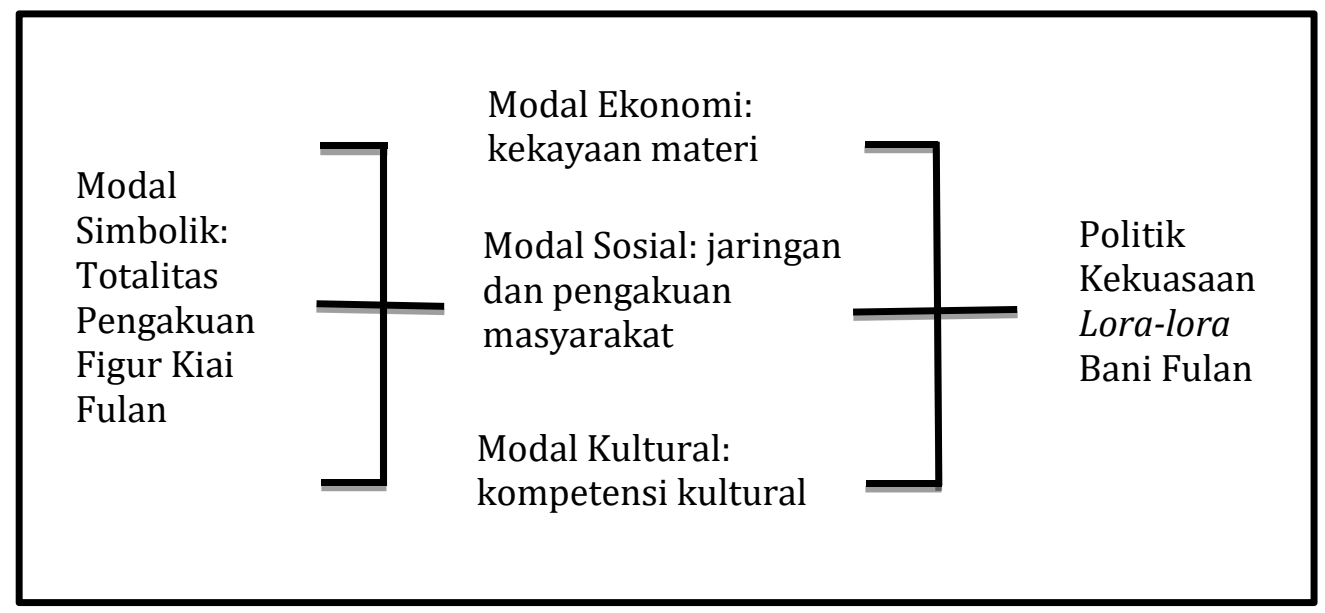

Gambar tersebut memperlihatkan bahwa modal utama lora-lora Bani Fulan yang dengannya memungkinkan mereka mengakumulasi modal-modal yang lain adalah modal simbolik yang melekat pada figur Kiai Fulan berikut dengan pengakuan dan totalitas penghormatan dan pengabdian para santri dan pengikutnya. Bersamaan dengan desentralisasi dan otonomi daerah, mereka berhasil memanfaatkan modal-modal ini untuk merebut kekuasaan politik melalui Pemilu dan Pilkada.

Berikut bagaimana modal simbolik menghasilkan modal-modal yang lain. Pertama, pesantren yang memiliki alumni ribuan orang dan tersebar di berbagai pelosok negeri dan luar negeri, lora-lora Bani Fulan mendapat sumbangan dari mereka untuk mengembangkan pesantren dan untuk memenuhi kebutuhan keluarga lora-lora Bani Fulan. Banyak di antara para alumni menjadi pengusaha kaya di Jakarta, Kalimantan, dan kota-kota lain di Indonesia. Tidak sedikit pula di antara alumni yang menjadi TKI di luar negeri dan memberikan sumbangan bagi pengembangan pesantren. Demikian pula orang tua yang anaknya nyantri juga ikut memberikan sumbangan material terhadap pembangunan pesantren. Jaringan 
alumni dan orang tua santri menjadi "modal" bagi lora-lora untuk mengembangkan pesantren. Bagi mereka yang bermaksud mendapat barokah Kiai Fulan kadangkala mereka memberikan sesuatu dalam bentuk materi atau uang, orang Madura menyebutnya "salam tempel". Hubungan religius-kultural ini memberikan keuntungan ekonomi bagi keluarga lora-lora Bani Fulan.

Kedua, pengakuan masyarakat Kabupaten BM terhadap "superioritas" Kiai Fulan dan trahnya sangat kuat. Lora-lora Bani Fulan betul-betul menjadikan hal ini untuk mempertahankan hegemoni dan supremasi mereka atas masyarakat dan kelompok-kelompok lain. Posisi mereka yang terhormat sebagai keturunan Kiai Fulan juga memungkinkan bagi mereka membangun jaringan regional dan nasional semakin mengukuhkan mereka di mata masyarakat. Pengembangan jaringan sosial ke lapisan masyarakat bawah juga mereka lakukan melalui santri dan orang tua santri. Bermodal kebesaran nama keluarga mereka dengan sangat mudah diterima oleh masyarakat, secara berkala mereka mendatangi masyarakat melalui penyelenggaraan pengajian, kumpulan shalawat, tahlilan, terbangan, selamatan, di kampung-kampung di pelosok-pelosok desa.

Ketiga, melalui karomah dan barokah Kiai Fulan, para lora Bani Fulan tampil sebagai tokoh panutan masyarakat dan pemimpin keagamaan. Mereka menggunakan kegiatan-kegiatan keagamaan seperti pengajian, tahlilan, sholawatan dan kegiatan-kegiatan yang bersifat spiritual seperti tawajjuhan untuk menjadi kompetensi dan supremasi kultural mereka di tengah masyarakat yang agamis-religius. Mereka juga menggunakan kelompok-kelompok seni keagamaan seperti terbangan dan bahkan mereka memiliki pengikut fanatik yang menempatkan salah seorang lora Bani Fulan sebagai pemimpin spiritual dan mursyid salah satu aliran Thoriqoh.

Ulasan di atas menunjukkan bahwa lebih dari hanya lokus kultural, pesantren telah mereproduksi dirinya menjadi lokus kekuasaan (locus of power) yang mempolakan relasi klientelistik berikut akumulasi beragam modal bagi lora Bani Fulan. Pesantren bukankah, secara spasial, hanya menjadi tempat orang belajar agama kepada kiai/lora, namun pesantren sekaligus telah menjadi tempat bagi mereka untuk menundukkan diri sepenuhnya bagi titah dan kebutuhan kiai/lora untuk mendapat keberkahan hidup. Tidak hanya itu, pesantren Bani Fulan juga menjadi pusat aktivitas politik, baik secara samar-samar, sembunyi-sembunyi, maupun terang-terangan. Di Kabupaten BM, tokoh-tokoh politik utama berada dalam lingkungan mikrokosmik pesantren, terutama pesantren-pesantren yang memiliki hubungan genealogis dengan Kiai Fulan, baik dari ikatan darah, ikatan pernikahan maupun relasi guru-murid.

\section{Poros Ikatan Kewargaan: Relasi Patron Klien Lora-Santri}

Dalam subkultur pesantren memang benar ada relasi klientelistik tidak dapat disangkal. Dalam subkultur pesantren relasi lora-santri dapat dilihat sebagai relasi antara patron dan klien. Kiai sebagai patron (panutan) sementara santri sebagai klien (pengikut). Namun dibaliknya tersimpan celah bagaimana kewargaan dirajut. Di balik relasi klientelistik tersebut tergambar bagaimana kiai dengan otoritas yang dimiliki menjadi tumpuan santri dan pengikutnya bagi kepentingan dan 
kebutuhan-kebutuhannya. Dibalik relasi klientelistik tersimpan moralitas yang dihidupi oleh para warga pesantren, kemaslahatan ummat. Di atas moralitas inilah kewargaan dirajut.

Karena posisinya sebagai pemimpin keagamaan lora menjadi patron bagi masyarakat yang bercorak agraris-agamis. Dalam bidang keagamaan, lora atau kiai adalah rujukan moral yang harus ditiru dan ditaati oleh santri. Pengajaran keagamaan di pesantren telah menjadi sistem keyakinan (worldview) yang menempatkan kiai sebagai rujukan spiritual santri (Rozaki 2016, 105). Pandangan keagamaan ini berpengaruh terhadap hubungan klientelisme di antara lora dan santri dalam bidang politik. Relasi lora-santri ini lebih dekat kepada pengertian klientelisme daripada patronase.

Berkaitan dengan konsep patronase dan klientelisme, Edward Aspinall dan Mada Sukmajati (2015) menyajikan perbedaan kedua konsep tersebut. Mereka merujuk pada Stefter (1994) dan Hutchroff (2014) yang membedakan konsep patronase dan klientelisme daripada Kitschelt dan Wilkinson (2007) yang menyamakan kedua konsep tersebut (Aspinall dan Sukmajati 2015, 3-4). Stefter dan Hutchroff mendefinikasikan patronase sebagai politik distribusi materi dan atau keuntungan lain oleh politisi kepada calon pemilihnya. Sedangkan klientelisme lebih menekankan pada relasi kekuasaan yang bersifat personal dan yang bersifat tatap muka langsung (Aspinall dan Sukmajati 2015, 4, dikutip dari Hutchcroff 2014 dan Scott 1972). Setidaknya terdapat tiga hal yang harus diperhatikan dalam memahami klientelisme. Pertama, terdapat hubungan timbal balik yang saling menguntungkan dan dipertukarkan antara patron dan klien. Kedua, relasi kekuasaan berlangsung secara hirarkis antara patron dan klien. Ketiga, terdapat perulangan pertukaran yang terus-menerus (Aspinall dan Sukmajati 2015, 4-5, dikutip dari Hicken 2011).

Seorang lora di Kabupaten BM tidak hanya menjadi patron bagi santri di bidang keagamaan belaka akan tetapi hubungan klientelisme mereka meluas pada bidang kehidupan yang lain, seperti sosial dan politik. Relasi klientelistik di antara lora dan santri dipolakan oleh pesantren sebagai habitus mereka. Pola patronase lora-santri terjadi melalui lembaga pesantren. Melalui pesantrenlah seorang kiai membangun pola klientelisme dengan santri, orang tua santri dan pengikutnya di desa-desa. Pola pengajaran di pesantren juga menyebabkan relasi patronase terjadi di antara lora dengan santri.

Dalam hal ini kiai memiliki posisi sentral untuk memberikan perkenannya bagi santri apakah sudah bisa dinyatakan lulus atau tidak dalam pelajaran dan diperbolehkan mengajar. Sistem ini yang membuat seorang santri akan terikat pada kiai mereka secara spiritual karena kiai/lora dianggap pembimbing seumur hidup (life-long tutor) (Wahid 1974). Hal ini tidak hanya berlaku bagi seorang kiai/lora yang masih hidup, bahkan pada kiai atau lora yang sudah meninggal pun santri mengikatkan diri sedemikian rupa kuatnya.

Ikatan dan hubungan sebagai guru dan murid di lingkungan pesantren Bani Fulan sangat kuat. Hal ini yang membuat hubungan patronase dan klientelisme yang dibangun atas "ideas" tertentu terlihat begitu kokoh dan tidak mudah dipatahkan oleh ide-ide baru yang datang dari dunia luar. Keterikatan santri 
kepada lora-lora Bani Fulan menciptakan "klientelisme budaya" (cultural clientelism) berbasis nilai keagamaan di antara santri-lora yang begitu kokoh dan kuat. Klientelisme berbasis budaya dan nilai keagamaan (clientelism based cultural and religious values) pada satu sisi mengokohkan relasi subordinasi santri dan superioritas lora dan pada sisi yang lain mempersulit hadirnya kewarganegaraan.

Di dalam subkultur pesantren terdapat nilai-nilai, kepercayaan dan norma yang menstrukturkan sikap dan perilaku santri di pesantren Bani Fulan. Bagi santri di pesantren Bani Fulan mendapat barokah kiai/lora adalah tujuan hidup. Barokah adalah idea pokok yang menginstalasi bagaimana santri mempersepsikan diri dan lora mereka dalam pesantren Bani Fulan. Konsep tentang barokah menjadi pengikat batin antara lora-santri Bani Fulan dimana dalam masyarakat yang akrab dengan tradisi pesantren yang kuat jika mendapatkan sesuatu yang menggembirakan, kesuksesan dalam hidup, karir yang menanjak dan kekayaan material, maka mereka akan mengatakan dengan lugas: ini semua karena barokah kiai/lora (guru) atau barokah pesantren.

Di Madura pernyataan tersebut sering diucapkan oleh santri dan orang tua santri yang anaknya mendapat kesuksesan hidup. Seperti digambarkan oleh perkataan dan perilaku santri di pesantren bani Fulan konsep tentang barokah kiai/lora telah menjadi kesepakatan moral di antara mereka. Santri di pesantren Bani Fulan memiliki cara untuk memperoleh barokah lora atau pesantren. Bagi seorang santri ngabule maupun ngabdi dianggap sebagai media yang dapat mengantarkan mereka untuk mendapatkan barokah dari kiai/lora dalam mengarungi kehidupan. Di sini terlihat relasi mutualisme antara keduanya, santri dan kiainya. Santri memberikan pengabdian dan loyalitas total kepada lora-nya, sementara lora melalui karomah yang dimilikinya memberikan barokah pada santri yang bersangkutan, paling tidak mendo'akannya agar mendapat barokah dalam hidup.

\section{Kesimpulan}

Analisis dalam kajian ini menunjukkan bahwa di pesantren tersedia tata nilai, ide, kepercayaan, norma, dan tradisi yang distrukturkan oleh, dan menstruktur ulang persepsi, apresiasi dan aksi para anggotanya (lora dan santri). Pesantren dengan segala unsur pembentuknya telah mempolakan relasi klientelistik lorasantri. Di dalam konstruksi sosial yang kokoh tersebut kewarganegaraan sulit hadir. Di pesantren juga bekerja ideas dan doxa yang menginstalasi persepsi dan perilaku lora dan santri. Selain itu, terdapat juga "simbol" yang selalu direpresentasi dan direproduksi untuk menjaga supremasi kultural dan legitimasi politik lora di hadapan santri, khususnya, dan masyarakat pada umumnya.

Seiring dengan perubahan politik pada tingkat makro, dengan modalitas simbolik yang dimiliki, para lora bertransformasi dari habitus lama (pesantren) ke habitus baru. Habitus baru mereka adalah masyarakat politik (partai politik dan organisasi masyarakat sipil) dan negara (lembaga eksekutif dan legislatif). Transformasi ini berlangsung melalui mekanisme demokrasi elektoral, pemilihan kepala daerah dan peilihan umum. Namun sayangya transformasi habitus yang 
terjadi pada lora berlangsung dalam relasi klientelismenya dengan santri. Oleh sebab itu, transformasi tidak memberikan efek-efek positif bagi hadir-tidaknya demos di dalam pesantren. Meskipun demikian, dibalik bekerjanya pesantren sebagai locus of power dan pola relasi klientelistik, terselip celah sense of public dan public morality yang dapat ditansformasi untuk memperkuat agenda demokratisasi di masa mendatang.[]

\section{Acknowledgements}

Artikel ini diadaptasi dari sebagian chapter dari Tesis saya yang diajukan untuk gelar Magister bidang Hak Asasi Manusia dan Demokrasi di Departemen Politik dan Pemerintahan, Fakultas Ilmu Sosial dan Ilmu Politik, Universitas Gadjah Mada, Indonesia, 2016.

\section{Daftar Pustaka}

Aspinall, Edward dan Mada Sukmajati. 2015. Politik Uang di Indonesia Patronase dan Klientelisme pada Pemilu Legislatif 2014. Yogyakarta: PolGov.

Bellamy, Richard. 2008. Citizenship A Very Short Introduction. Oxford: Oxford University Press.

Bourdieu, Pierre. 1977. Outline of A Theory of Practice. Cambridge: Cambridge University Press.

Bourdieu, Pierre. 1990. The Logic of Practice. Stanford: Stanford University Press.

Bourdieu, Pierre. 1984. Distinction: a Social Critique of the Judgment of Taste. Cambridge Massachusetts: Harvard University Press.

Bruinessen, Martin Van. 1994. NU: Tradisi, Relasi-Relasi Kuasa, Pencarian Wacana Baru. Yogyakarta: LKiS.

Geertz, Clifford. 1960. "The Javanes Kijaji: The Changing Role of a Cultural Broker." Comparative Studies in Society and History 2, no. 2 (January): 228-249.

Hadimulyo. 1985. “Dua Pesantren Dua Wajah Budaya.” Dalam Pergulatan Dunia Pesantren Membangun Dari Bawah, diedit oleh M. Dawam Rahardjo. Jakarta: P3M.

Atkinson, Paul, dan Martyn Hammersley. 2009. "Etnografi dan Observasi Partisipan." Dalam Handbook of Qualitative Research, diedit oleh N.K. Denzin dan Y. Lincoln, 316-334. Yogyakarta: Pustaka Pelajar.

Hochschild, Jennifer L. 2006. "How Ideas Affect Action." Dalam The Oxford Handbook of Contextual Political Analysis, diedit oleh Robert E. Goodin dan Charles Tilly. Oxford: Oxford University Press. 
Horikoshi, Hiroko. 1987. Kyai dan Perubahan Sosial. Jakarta: P3M.

Jenkins, Richard. 1992. Pierre Boudieu. London: Routledge.

Jenkins, Richard. 2004. Membaca Pikiran Bourdieu. Yogyakarta: Kreasi Wacana

Maarif, Ahmad Syafii. 2009. "Masa Depan Islam di Indonesia." Prolog dalam Ilusi Negara Islam, diedit oleh Abdurrahman Wahid, 7-10. Jakarta: The Wahid Institute.

Nordholt, Henk Schulte. 2005. "Desentralisasi di Indonesia: Peran Negara Kurang, Lebih Demokratis?.” Dalam Politisasi Demokrasi Politik Lokal Baru, diedit oleh Jhon Haris, Kristian Stokke, dan Olle Tornquist. Jakarta: Demos.

Priyono, A.E., Willy Purna Samadhi, dan Olle Tornquist. 2007. Menjadikan Demokrasi Bermakna Masalah dan Pilihan di Indonesia. Jakarta: Demos.

Priyono, B. Herry. 2014. "Pada Mulanya adalah Lagak: Habituasi sebagai Kunci Institusionalisasi Demokrasi." Dalam Merancang Arah Baru Demokrasi Indonesia PascaReformasi, edited by AE. Priyono dan Usman Hamid. Jakarta: KPG.

Putri, Vegitya Ramadhani. 2012. Denizenship Kontestasi dan Hibridasi Ideologi di Indonesia. Yogyakarta: PolGov.

Rozaki, Abdur. 2016. Islam, Oligarki Politik dan Perlawanan Sosial. Yogyakarta: Pasca Sarjana UIN Sunan Kalijaga dan SUKA Press.

Rozaki, Abdur. 2004. Menebar Kharisme Menuai Kuasa Kiprah Kiai dan Blater sebagai Rezim Kembar di Madura. :Pustaka Marwa.

Rueschemeyer, Dietrich. 2006. "Why and How Ideas Matter." Dalam The Oxford Handbook of Contextual Political Analysis, edited by Robert E. Goodin dan Charles Tilly. Oxford: Oxford University Press.

Santoso, Purwo. 2004. "Demokratisasi: Suatu Telaah Politico-Cultural." Dalam Politik Transisi Pasca Soeharto, edited by Eric Hiariej, Ucu Martanto dan Ahmad Musyaddad, 63-88. Yogyakarta: Fisipol UGM.

Santoso, Purwo. 2012. "Watak Hibridasi dalam Wacana Citizenship di Indonesia." Pengantar dalam Denizenship Kontestasi dan Hibridasi Ideologi di Indonesia, Vegitya Ramadhani Putri. Yogyakarta: PolGov.

Savirani, Amalinda. 2015. "Demands for Welfare Rights but Fragmented Demos." Dalam Reclaming the State Overcoming Problems Democracy in Post-Soeharto Indonesia, diedit oleh Amalinda Savirani dan Olle Tornquist. Yogyakarta: PolGov dan PCD Press. 
Spradley, P. James. 2006. Metode Etnografi. Yogyakarta: Tiara Wacana.

Steward, Angus. 1995. "Two Concepts of Citizenship." The British Journal of Sociology 46, no. 1 (Maret): 63-78.

Stokke, Kristian dan Elin Selboe. 2009. "Symbolic Representation as Political Practice." Dalam Rethinking Popular Representation, edited by Olle Tornquist, Neil Webster dan Kristian Stokke. New York. Palgrave Macmillan.

Suseno, Frans Magnes. 1995. Mencari Sosok Demokrasi Sebuah Telaah Filosofis. Jakarta: Gramedia.

Thohari, Slamet, dan Indhar Wahyu Wira Harjo. 2021. Teori Sosial: Antara Individu dan Masyarakat. Malang: UB Press.

Veeger, K.J. 1985. Realitas Sosial Refleksi Filsafat Sosial atas Hubungan IndividuMasyarakat dalam Cakrawala Sejarah Sosiologi. Jakarta: Gramedia.

Wahid, Abdurrahman. 1974. "Pesantren sebagai Subkultur." Dalam Pesantren dan Pembaharuan, diedit oleh M. Dawam Rahardjo. Jakarta: LP3ES.

Wiyata, A. Latief. 2002. Carok: konflik kekerasan dan harga diri orang Madura. Yogyakarta: LKiS.

\section{Biografi Penulis}

Insan Kamil adalah Ketua Dewan Pimpinan Daerah Partai NasDem Kabupaten Situbondo. Ia menyelesaikan program Magister bidang Hak Asasi Manusia dan Demokrasi di Departemen Politik dan Pemerintahan, FISIPOL, Universitas Gadjah Mada, Indonesia. Selain aktivis partai politik, ia memiliki rekam jejak yang cukup lama sebagai aktivis yang bergelut di bidang Demokrasi dan Hak Asasi Manusia. Email: sibratih.kamil01@gmail.com 